\title{
FACTORS INFLUENCING THE QUALITY OF FINANCIAL AUDIT
}

\author{
Camelia-Daniela Hategan \\ West University of Timisoara \\ camelia.hategan@e-uvt.ro
}

\begin{abstract}
Investors' decisions are based on financial and non-financial information. To be useful, the information provided by the financial reports must be accurate, which is also ensured by the opinion expressed by the auditors. The purpose of the paper is to show the importance of the quality of audit services both for investors and for professional accountants and auditors. Audit quality factors can be structured according to several criteria and were represented by the size of the auditor, rotation, duration of the contract, types of services provided. In order to support this hypothesis, the correlation between the variables was tested on the basis of a sample of seven companies listed at Bucharest Stock Exchange in the energy field and utilities included in index BET, for period 2013 - 2018. The data was collected from the annual financial statements and reports issued by financial auditors. The results show that there is a correlation between variables, but of different intensities depending on the indicators chosen. Increasing the quality of financial reporting and the quality of audit leads to increased investor confidence in professional accountants.
\end{abstract}

Keywords: audit quality, financial statements, audit opinion, factors

JEL classification: M41, M42

\section{Introduction}

According to International Standard on Auditing (ISA) 200 "Overall Objective of the Independent Auditor, and the Conduct of an Audit in Accordance with International Standards on Auditing", issued by The International Auditing and Assurance Standards Board (IAASB) For the opinion, the auditor is required to obtain reasonable assurance about the absence of material errors in the information contained in the financial statements under review.

An essential link to be outlined is that of expressing a quality opinion without influences or distortions and factors that can have an impact on opinion audiences, which is directly proportional. Thus, when a potential risk factor, which is not adequately prevented and / or controlled, appears to have a direct impact on the quality of the expressed opinion, this is influenced by the auditor's reasoning. The reason for this discussion will be the factors that can influence the auditor's reasoning as well as the quality concept of the opinion issued by the auditor.

In order to analyze the factors that may influence the auditor's opinion seven companies listed on the Bucharest Stock Exchange (BVB) were analyzed. Entities were chosen from the field of energy and utilities to ensure better comparability, the data were taken from the financial statements, the administrators 'reports and the auditors' reports. From data processing were identified the auditor's opinions on the financial statements, the date when the auditors changed, the fees charged for the services rendered.

Starting from the processed results, an econometric model on the relationship between the factors that could influence the auditor's opinion was tested in the second stage, so the following variables were selected auditor size, auditor change, evolution of fees as a share of turnover. 
The research will contribute to the development of the literature as it provides an analysis of the available data on auditors' reports for the companies surveyed from a perspective geared to the importance and necessity of public disclosure of all information on the relationship with financial auditors.

The paper is structured as follows: the second section contains a summary of the relevant literature on the quality of the audit, while the third section describes the research methodology. The fourth section presents the results of the study along with our comments. The last section includes the conclusions, limitations of the study and future research directions.

\section{Literature review}

The literature on the quality of the audit and its measurement is vast; but despite the scope of this literature, numerous studies and legislation in place, there is no generally accepted definition of the quality of audit. From this point of view, DeAngelo (1981) gives an appropriate definition, according to which the quality of the audit results from the "probability that an auditor will discover and report a breach of regulations in the client's accounting system. The discovery of distortion depends on the quality and volume of knowledge gained and the auditor's capacity, while the reporting of distortion depends on the auditor's motivation to disclose it. "

The definition given by DeAngelo is in line with that of the IAASB, but it makes it much clearer that detection of an irregularity is not sufficient, and it is essential that steps be taken to take appropriate steps such as correcting or reporting the error. In order to perform a quality audit, any detected irregularity that may have an impact on the information in the financial statements must be adequately corrected. To improve the quality of the audit, IAASB has developed a new standard on the content of the auditor's report that presents users with more information, applicable starting with the financial statements of year 2016 (ISA 700).

The study of Malihi et al. (2013) complements this definition, thus defining the intrinsic factors for an audit mission: the auditor's ability to perform an activity in accordance with the required standards and its independence. The freedom to take the necessary measures without the risk of some personal or professional repercussions that may result from expressing an opinion contradictory to what the client desires.

The definition was update by DeFond and Zhang (2014) to "greater assurance that the financial statements faithfully reflect the firm's underlying economics, conditioned on its financial reporting system and innate characteristics."

These definitions outline risk areas where influences may arise on the auditor's judgment in expressing opinions and therefore present the risks that require particular attention so that their impact does not affect the quality of the audit engagement and the opinion expressed because of it, resulting in an effective audit.

As a result of the ideas outlined by DeAngelo in 1981, numerous researches by field professionals in both emerging economies and developed economies has been conducted to identify various factors that have an impact on the quality of an audit and how they vary from one sector to another. Among the factors discussed are the degree of specialization of the auditors regarding the information analyzed, the size of the audit company undertaking the mission, the level of remuneration, the level of certification of the auditors, the level of collaboration with professionals from other auditor specialties, the period of collaboration. Another factor debated in contemporary literature that can influence the audit mission and therefore the opinion issued is how the auditor is called. Through a study by Hameed (1995), a number of pivotal factors have emerged in expressing a high-quality external audit opinion, namely: audit team experience, honesty / professional ethics and professional knowledge in accounting and auditing matters. Another factor of influence for the audit opinion was the 
degree of specialization of the industry and its regulation. According to a study led by Dunn and Mayhew (2004), were concluded that in a highly specialized industry lacking specific operating and regulatory standards to conduct a quality audit it is necessary to use a specialized auditor with a specific knowledge. Next, the following factors will be analyzed in depth: the size of the audit firm, the level of audit fee and, the duration of the audit mandate.

\subsection{The size of the audit company}

DeAngelo (1981) thoroughly examined the potential impact that the size of the audit service provider may have on the opinion expressed on the correctness of the information contained in the audited financial statements. As a result of this study, it was concluded that the size of the audit service provider is sufficient to inflate the audit opinion issued, as it is highlighted that a large company in terms of number and diversity of clients will perform a mission with a higher quality than a small company, which is not dependent on one or two clients. This implication leads to the conclusion that an external audit service provider with a large number of clients will not suffer substantial losses from such a situation, but on the contrary, in the case of a reputable company such as big companies (Big 4), conducting an audit with a a low level of quality could lead to much greater losses. The more the company has more customers, the more it has to lose. DeAngelo (1981) emphasizes the risk that a client with a limited portfolio of clients may have a relationship of dependence between the client and client. In such cases, misunderstandings that may result from expressing an opinion contrary to what the customer desires may result in loss, which may have a substantial impact on a company's revenue with a limited number of clients, which risks the auditor not reporting all the irregularities, discovered so to maintain its source of income.

Craswell et al. (1995) conduct a study of this potential influence factor on the auditor's judgment to evaluate DeAngelo's conclusions. It uses a sample of 1,484 public companies in Australia using data gathered over an 8-year period to study their evolution over time. The conclusion reached was that audit service providers with a larger market share carry out higher quality audit missions. It outlined, however, that these companies are using higher rates, up to $35 \%$ higher than small companies, which allows them to invest substantial amounts in the specialization of employees and in developing the systems they use.

A similar study was conducted by Becker et al (1998), using a sample of 12,500 companies over a 3-year period. The results of this study are similar to those found by Craswell et al. (1995), the revenue of a larger auditing company stems both from the high number of customers and from the higher rates they use. However, like DeAngelo (1981), he outlined that these companies risk losing more if their reputation is affected than by losing customers. Thus, the risk of these auditors being influenced is much lower than in the case of a small company.

Contrary to the above findings, a study by Louis and Robinson (2005), on a sample of seven Korean companies that had previously been fraudulent, did not identify any qualitative difference between the financial statements audited by a Big 4 and a small one. The main difference, however, is the brand effect that suggests a much higher degree of confidence attributed to the report and thus to the information in the financial statements.

This association of high-grade audit firm size has arisen due to the difficulty in assessing the quality of the work done by auditors and the increasing interest of users of financial statements on this subject. The main elements of influence attributed to this factor are the dependency relationship between the client and the supplier, the share of client revenue with total portfolio, the degree of audit development and the incentives offered to guarantee the identification and reporting of potential irregularities, the value attributed to the reputation the auditor created over time (especially Big 4), etc.

Users of financial information regard the audit opinion as assurance on the reality of the material presented by a company, raising their value. The reason why, from the perspective of a potential user, the level of trust suggested by the auditor who has accredited the 
information is essential. Considering the difficulty with which product quality can be inferred for consumers, the reputation of the supplier has become a pivotal factor in determining the level of confidence that can be given.

The reputation of audit service providers is gained through practice, longevity, consistency and quality. Thus, we can see that the highest degree of trust is attributed to Big 4 companies, which have a monopoly on this market. The reputation acquired by practitioners is strengthened with every customer and opinion issued, but it can easily be missed with the wrong opinion. What this case proves is that once consumer confidence in the quality of service offered by a supplier is lost, it risks losing its market share.

\subsection{Financial dependence on the client}

As stated above, the composition of the auditor's revenue has a strong impact on its objectivity. Thus, if a high percentage of the auditor's income is composed of audit fees paid by a single client, there is a risk of dependence on it that is contrived by two possible scenarios that can influence the quality of the expressed opinion: the emergence of own interest in the result obtained or the risk of intimidation, both derive from the substantial financial impact of the customer's loss. It should be noted that under certain circumstances, the quality of an audit could be questioned even if there is no relationship of dependence between the client and the auditor, and only the appearance of one that will impose a high degree of skepticism on the outcome of a mission, questioning the objectivity of the auditor. This proves the importance of transparency in customer interactions.

However, the level of remuneration is not a factor that warrants the occurrence of a problem, this depends on a number of determining factors such as: the structure of the firm providing the audit service, the significance of the client in terms of revenue, if the firm is established on the market (Big 4) having gained a high degree of experience and prestige, or if it is a relatively new company that has not yet created a solid portfolio of clients, etc. In order to counteract the impact of these possible risk factors, the auditor has to implement various tactics such as: applying a system of external verification of the quality of the services offered, calling for external consultancy from professionals and reducing dependence on the margin of income earned from main customers by diversifying and expanding customer portfolio.

\subsection{The duration of the audit mandate}

One factor of influence that has been determined by scandals in recent decades and which has been concerned by experts in the field is the duration of the audit mandate. The main reason that led to the discussion was the concern about the possible impact on the auditor's independence.

Independence is a key factor in maintaining the ethical behavior of the auditor (Lin and Tepalagul, 2015). It involves maintaining an objective attitude towards the client, i.e. avoiding relationships of dependence or influence between the parties involved. In order to carry out his duties an auditor must maintain his skeptical attitude during the mission, an attitude that can disappear with familiarity with the client. Moreover, in order to maintain the relationship with the client, he may ignore or even hide certain evidence that would otherwise lead to the creation of disputes concerning the fairness of the information presented in the financial statements.

A study by Hsieh (2011) indicated that an audit conducted for the first time by a new auditor is of a lower quality than in the following years. A detailed analysis of this issue has suggested low value causality attributed to the lack of detailed information about the client's expertise rather than to the level of effort made by the auditor. Another suggestion of this study has indicated that this deficit may be caused by the auditor's intention to retain the client for the coming years by providing a favorable result. 
Another study led by Siregar et al. (2012) in Indonesia, following the implementation of specific legislation related to the duration of the mandate for auditors at 3 or 5 years as the case may be, suggested that rotation of audiences does not often have a positive impact on the quality of work, but leads to the loss of know-how and the loss of their ability to detect certain customer-specific errors. While a prolonged mandate helps the auditor to become familiar with the client's activity in order to identify weaknesses in how reporting and activity-specific risks, the quality of the audit increases with familiarity to a certain point.

However, studies suggest that auditor change may have negative consequences on the stock market of a company if the switch is made from Big 4 to another or a local company, and is often interpreted as an unlawful move to hide potential errors. At the same time, an opposite effect occurs when a company changes its auditor by opting for a Big 4 instead of an "obscure" service provider, or when the change occurs due to the object of activity or for an obvious reason for users of the financial information.

\section{Methodology}

The case study is based on research into the factors that influence the auditor's opinion on the financial statements. The sample consists of seven companies listed and traded on the BSE in the oil, electricity and natural gas, which forms the BET index, between 2013 and 2018.

The motivation for choosing the sample is that the seven companies have close business area and there are the largest companies in the country and are vital to Romania's economy. The chosen period was determined by the existence of the data and the split of the period in 2 stages 2013-2015 and 2016-2018, as a result of the change in the content of the report issued by the auditors for the financial statements of 2016. The data used for the study were collected from the company's annual reports and were confronted with the official data.

The auditor's opinion on financial statements may be influenced by several factors that have been tested on econometric model, as a relationship between the dependent variable - the auditor's opinion and the independent variables: auditor change, auditor size category, fee evolution, as a percentage of turnover, the independent auditor's report (new or old model) and the company's governance system. Table 1 shows how to represent these indicators.

Table 1: Description of variables

\begin{tabular}{|l|l|}
\hline \multicolumn{1}{|c|}{ Variables } & \multicolumn{1}{c|}{ Explanations } \\
\hline Auditor's opinion (Oa) & $\begin{array}{l}1-\text { if the opinion was unqualified } \\
0-\text { if the opinion was qualified }\end{array}$ \\
\hline Auditor rotation (Ro) & $\begin{array}{l}1-\text { if the auditor was changed in the reference period } \\
0-\text { if the auditor wasn't changed in the reference } \\
\text { Period }\end{array}$ \\
\hline Size of the auditor (Sa) & $\begin{array}{l}1-\text { if the auditor belongs of Big 4 group } \\
0-\text { if the auditor belongs of non-Big 4 group }\end{array}$ \\
\hline Evolution of audit fee - & $\begin{array}{l}1 \text { - if the share of audit fee increased, compared to the } \\
\text { previous period } \\
0-\text { any other situation }\end{array}$ \\
\hline Auditor's report (Ra) & $\begin{array}{l}1-\text { new auditor's report starting with year 2016 } \\
0-\text { old auditor's report }\end{array}$ \\
\hline Governance system (Gov) & $\begin{array}{l}1-\text { if the governance system of company is unitary } \\
0-\text { if the governance system of company is dual }\end{array}$ \\
\hline
\end{tabular}

Source: Author's compilation, 2019 
The regression equation will be linear multifactor type according to the following formula:

$$
\mathrm{Oa}=\alpha_{i t}+\beta_{1} R o+\beta_{2} \mathrm{Sa}+\beta_{3} \mathrm{Fa}+\beta_{4} R \mathrm{a}+\beta 5 \mathrm{Gov}+\varepsilon_{i t}
$$

To determine the power of explanation of the proposed model, hypothesis testing will be performed by several models that will include all independent variables, as well as testing only with variables whose statistical significance will be more relevant.

\section{Results}

The information presented in the independent auditors' reports on the audit of financial statements are compiled in Table 2.

Table 2: Information regarding the auditors and corporate governance

\begin{tabular}{|l|l|c|c|c|}
\hline No & \multicolumn{1}{|c|}{ Company's name } & $\begin{array}{c}\text { Qualified } \\
\text { opinion }\end{array}$ & $\begin{array}{c}\text { Changes the } \\
\text { auditors }\end{array}$ & $\begin{array}{c}\text { Governance } \\
\text { system }\end{array}$ \\
\hline 1 & OMV Petrom S.A. & No & No & Dual \\
\hline 2 & S.N.G.N. Romgaz S.A. & No & Yes, in 2018 & Unitary \\
\hline 3 & C.N.T.E.E. Transelectrica & $\begin{array}{c}\text { Yes, in } 2013 \\
\text { and 2018 }\end{array}$ & $\begin{array}{c}\text { Yes, in 2014 } \\
\text { and 2018 }\end{array}$ & Dual \\
\hline 4 & Soc Energetica Electrica S.A. & Yes, in 2013 & Yes, in 2018 & Unitary \\
\hline 5 & S.N.T.G.N. Transgaz S.A. & No & $\begin{array}{c}\text { Yes, in 2015 } \\
\text { and 2018 }\end{array}$ & Unitary \\
\hline 6 & S.N. Nuclearelectrica S.A. & $\begin{array}{c}\text { Yes, in all } \\
\text { period }\end{array}$ & $\begin{array}{c}\text { Yes, in 2014 } \\
\text { and 2017 }\end{array}$ & Unitary \\
\hline 7 & Conpet S.A. & No & Yes, in 2016 & Unitary \\
\hline
\end{tabular}

Source: Author's compilation, 2019

Table 2 shows that in four companies the auditors issued unqualified opinions throughout the period under review. It stands as OMV Petrom SA maintained the same auditor, and S.N. NUCLEARELECTRICA S.A. is the only company in the sample to which the auditors have issued a qualified opinion on the financial statements throughout the analyzed period. Regarding the corporate governance system, most companies have a unitary structure of governance.

In order to highlight the factors influencing the opinion of the auditors, a descriptive statistic of the analyzed indicators presented in Table 3 was made.

Table 3: Descriptive statistics

\begin{tabular}{|l|c|c|c|}
\hline \multicolumn{1}{|c|}{ Variables } & Mean & $\begin{array}{c}\text { Standard } \\
\text { Error }\end{array}$ & $\begin{array}{c}\text { Standard } \\
\text { Deviation }\end{array}$ \\
\hline Auditor's opinion (Oa) & 0.7851 & 0.0641 & 0.4153 \\
\hline Auditor rotation (Ro) & 0.2143 & 0.0641 & 0.4153 \\
\hline Size of the auditor (Sa) & 0.7381 & 0.0687 & 0.4450 \\
\hline $\begin{array}{l}\text { Evolution of audit fee - } \\
\text { percentage in turnover (Fa) }\end{array}$ & 0.3810 & 0.0758 & 0.4915 \\
\hline Auditor's report (Ra) & 0.5000 & 0.0781 & 0.4572 \\
\hline Governance system (Gov) & 0.7823 & 0.0706 & 0.5061 \\
\hline
\end{tabular}

Source: Author's compilation, 2019 
Thus, from the total number of observations of 42 (representing 7 companies per 6 years) on average $78.51 \%$ cases have been reported unmodified auditor's opinions. The auditor was changed in the case of $21.43 \%$ of the number of observations and $73.81 \%$ of the analyzed financial statements were audited by auditors belonging to the Big 4 group. In addition, an average of $38.10 \%$ of the observations increased the share of auditors' annual fee in turnover. In order to have comparable data in terms of considering the auditor's report chosen, given the period selected, half of the number of observations was taken from the new audit reports.

The correlation between variables is presented in Table 4, which shows that the dependent variable, the auditor's opinion is in a positive correlation with the size of the auditor (0.61). Of the independent variables, the most relevant positive correlations were identified between the governance system variable, which has a moderate correlation with the size of the auditor (0.38), and the evolution of the auditor fee (0.26). It is also worth mentioning the negative correlations of the auditor size variable with the rotation of the auditors $(-0.35)$, as well as the auditor's report model. (-0.27)

Table 4: Correlation matrix

\begin{tabular}{|l|c|c|c|c|c|c|}
\hline & Oa & Ro & Sa & Fa & Ra & Gov \\
\hline Oa & 1 & & & & & \\
\hline Ro & -0.1515 & 1 & & & & \\
\hline Sa & 0.6127 & -0.3488 & 1 & & & \\
\hline Fa & -0.0683 & 0.1878 & -0.0903 & 1 & & \\
\hline Ra & 0.0580 & 0.1741 & -0.2708 & 0.0981 & 1 & \\
\hline Gov & 0.2018 & -0.0734 & 0.3767 & 0.2636 & 0 & 1 \\
\hline
\end{tabular}

Source: Author's compilation

From the econometric model, the change of the independent variables influences $87 \%$ the change of the dependent variable, according to the data in Table 5.

Table 5: Regression's results

\section{Regression Statistics}

Multiple R

$R$ Square

Adjusted R Square

Standard Error

Observation

\subsection{1}

0.8726

0.8318

0.3377

ANOVA

\begin{tabular}{|l|r|r|r|r|r|}
\hline & \multicolumn{1}{|c|}{ df } & \multicolumn{1}{c|}{ SS } & MS & F & Significance F \\
\hline Regression & 5 & 28.7965 & 5.7593 & 50.6939 & 0.0000 \\
\hline Residual & 37 & 4.2035 & 0.1136 & & \\
\hline Total & 42 & 33 & & & \\
\hline
\end{tabular}

\begin{tabular}{|l|r|r|r|r|}
\hline & \multicolumn{1}{|l|}{ loefficients } & \multicolumn{1}{c|}{ Standard Error } & \multicolumn{1}{c|}{ t Stat } & \multicolumn{1}{c|}{ P-value } \\
\hline Intercept & 0 & \#N/A & \#N/A & \#N/A \\
\hline Ro & 0.1194 & 0.1297 & 0.9205 & 0.3633 \\
\hline Sa & 0.8278 & 0.0845 & 9.7994 & 0.0000 \\
\hline Fa & 0.0248 & 0.1105 & 0.2240 & 0.8240 \\
\hline Ra & 0.2762 & 0.0945 & 2.9231 & 0.0059 \\
\hline Gov & -0.0836 & 0.1301 & -0.6428 & 0.5243 \\
\hline
\end{tabular}

Source: Author's compilation, 2019 
After testing the model with all the independent variables, it was found that, the model was validated for the auditor size variable. In addition, another variable of great significance is the variable, the model of the report, according to the data in Table 5.

Contrary to expectations, the rotation of the auditors and the evolution of their fees do not have a significant influence on the auditor's opinion on the financial statements of the companies in the analyzed sample. If higher audit fees are associated with greater audit effort or a fee for auditing specialization, the audit quality could be expected to be higher. Contrarily, relatively higher audit fees could lead the auditor to become financially dependent on the client, thereby eroding the independence. In our case, the opinions of the auditors of the seven companies required greater efforts by the economic entity to carry out a higher volume of audit procedures that led to an increase in fees from year to year, resulting in the quality of the information transposed in the auditor's report. As the turnover of the financial years 2013-2018 shows increased financial performance, it involves a high audit risk of applying additional audit procedures to reduce this risk, with a direct impact on audit fees, in order to increase them.

Thus, high audit fees are justified by the increase in audit procedures performed by the auditor to reduce audit risk. The study considers the impact of audit fees on audit quality in two ways: high audit fees paid to auditors may reflect the complexity of the audit process and increase the auditors' effort. However, higher auditing fees paid to auditors could help build the financial link between the client and the auditors, so that auditors are easier to compromise for the independence of the audit, for fear of losing highly profitable fees.

\section{Conclusion}

The topic of the quality of financial audit remains an important subject to be followed by users of financial statements for investment decisions or other strategic decisions. Issuing by auditors of opinions based on a high degree of professionalism contribute to increasing the confidence of all stakeholders on their activity. Practice can bring different audiences to different audiences, but by rigorously applying audit standards and using professional judgment, the most effective views on an audit mission can be built.

An important conclusion that comes after this work is that the auditor's opinion is based on professional judgment, but in practice, it can be influenced by the size of the audit firm materialized by the experience gained, similar with results of DeAngelo (1981) and Francis and $\mathrm{Yu}$ (2009). Other factors that can influence the opinion are the size of the fees and the duration of the contract.

The results of the study showed that the auditor's opinion does not modify at the change of audit firm from year to year, this is the same regardless of the contracted auditor. While it is certain that, the increase in turnover involves investigating higher auditor's financial risks. In the course of the analysis it was also found that in most cases the change of the auditor led to the increase of the audit fee from one year to the next, depending also on the risks associated with the economic entity.

The paper can be a bibliographic source for researchers in the field of accounting and financial audit, for managers of companies to understand the necessity and importance of drawing up financial quality reporting, as well as for the practitioners of the accounting profession who find in the paper a number of factors that can influence the auditor's opinion. The limits of the research consisted in the fact that the size of the sample was small, but was justified by the need for data comparability. In addition, a limitation factor is the lack of certified databases and no history of long-term information about rotation and auditor fees. Future research directions can be translated into expanding the number of companies and the period under study, as well as analyzing the correlation between the quality of financial reporting and the quality of financial audit. 


\section{References}

Becker, C., DeFond, M., Jiambalvo, J. and Subramanyam, K.R., 1998. The Effects of Audit Quality on Earnings Management, Contemporary Accounting Research, 15, pp. 1-24.

Craswell A. T., Francis J. R. and Taylor S. L., 1995. Auditor brand name reputations and industry specialization, Journal of Accounting and Economics, 20, pp. 297-322.

DeAngelo L. E., 1981. Auditor size and audit quality, Journal of Accounting and Economics, 3, pp. 183-199.

DeFond, M. and Zhang, J., 2014. A review of archival auditing research. Journal of Accounting and Economics, 58 (2-3), pp. 275-326.

Dunn, K. A. and Mayhew, B. W., 2004. Audit firm industry specialization and client disclosure quality. Review of Accounting Studies, 9 (1), pp.35-58.

Francis, J. and Yu, M., 2009. The effect of big four office size on audit quality. The Accounting Review, 84 (5), pp. 1521-1552.

Hameed, A., 1995. Characteristics of internal auditing quality, field study in the Saudi Arabia, General Management Journal, 35, pp. 405-451.

Hsieh, M.T., 2011. Does audit partner tenure influence on audit quality? Asian Journal of Management, 8, pp. 11-26.

Lin, L. and Tepalagul, N. K., 2015. Auditor Independence and Audit Quality: A Literature Review, Journal of Accounting, Auditing and Finance, 30 (1), pp. 101- 121.

Louis H. and Robinson D., 2005. Do managers credibly use accruals to signal private information Evidence from the pricing of discretionary accruals around stock splits? Evidence from Korean manufacturing share companies, Journal of Accounting and Economics, 2, pp. 18-74.

Malihi, S. A., Mahdavikhou, M. and Khotanlou, M., 2013. An Investigation into the Relationship between Audit Committee and Audit Quality, Australian Journal of Basic and Applied Sciences, 6 (10), pp. 409-416,

Siregar, S. V., Amarullah, F., Wibowo, A. and Anggraita, V., 2012. Audit tenure, auditor rotation, and audit quality: the case of Indonesia. Asian Journal of Business and Accounting, 5 (1), pp. 55-74.

IFAC, IAASB, 2012. ISA 200 Overall Objective of the Independent Auditor, and the Conduct of an Audit in Accordance with International Standards on Auditing, Available on line at: https://www.ifac.org/publications-resources/2012-handbook-international-quality-control-au diting-review-other-assurance-a [accessed on June 25, 2019]

IFAC, IAASB, 2015. ISA 700 (Revised), Forming an Opinion and Reporting on Financial Statements, Available on line at: https://www.ifac.org/publications-resources/international-standard-auditing-isa-700-revised -forming-opinion-and-reporting [accessed on June 25, 2019].

\section{Bio-note}

Camelia-Daniela Hategan, PhD, is Associate Professor in the West University of Timisoara, Faculty of Economics and Business Administration, Accounting and Auditing Department and from February 2018 Doctoral Supervisor in Accounting. The author's areas of interest in research include Financial Accounting, International Financial Reporting Standards, Financial Audit, Entrepreneurship in the accounting profession and Corporate Social Responsibility. She published and presented numerous papers in this field in scientific journals and conference proceedings; also, she has been participating in multiannual grants as a director or as a member. 